\title{
Function Words of Buol Language Examined from Syntactical Features
}

\author{
Baso Andi-Pallawa \\ Department of English language and Teaching \\ Faculty of Teachers Training and Educational Sciences \\ Tadulako University, Palu, Middle Sulawesi Province, East Indonesia, January, 2005 \\ Tel: 620-813-3396-9613Ｅ-mail: andipallawab@rocketmail.com \\ Dr. Andi Fiptar Abdi Alam (Corresponding author) \\ Faculty of Education of Tadulako University \\ Kampus Bumi Tadulako Tondo Tlp. 429743, Centre: 246,247,249,250 \\ Palu City, Middle Sulawesi Province, East Indonesia
}

Received: June 9, 2013 Accepted: June 22, 2013 Published: June 23, 2013

doi:10.5296/ijele.v1i3.3893 URL: http://dx.doi.org/10.5296/ijele.v1i3.3893

\begin{abstract}
To avoid not to receive the new words from loan words, the syntax of Buol language, especially its function words, must be investigated in details to keep the original structures of this language survive without being influenced by other vernaculars, and far from being extinction. In line with this information, this study portrays the function words of Buol language in terms of the function word varieties such as 1) noun clarifiers, 2) modifier, 3) prepositions, 4) coordinators, 5) interrogators, 6) subordinating conjunction, 7) sentence linkers, 8) modal auxiliaries, 9) interjection, 10) aspect words, and (11) relative pronouns. The importance of this study is required to create the narrative data of those varieties of function words, to provide information for those who are keen on conducting another study dealing with Buol language, to assist the teaching of local subject matter course, such as function words themselves of Buol language and to play a role to the Department of National Education, especially in Central Sulawesi for the consideration as development of the local subject matter course curriculum. The pattern of this inquiry is descriptive qualitative. It is founded on the process of scrutiny involving description and interpretation that can be exerted without controlling any variables. The informants of this study are ten native speakers of Buol language at Buol regency living permenantly in one of five districts called Biau district.
\end{abstract}

Keywords: function words, syntactical features, Buol language 


\section{Introduction}

In general, the population of Buol Regency use the Indonesian language as the National Language (= Bahasa Indonesia) of the Indonesian Republic, and Buol vernacular via only one dialect as a tool of their daily life communication at five districts: a) Biau district, b) Momunu district, c) Bokat district, d) Bonubogu district, and e) Palele district. This Buol regency is situated to the North part of Sulawesi along beach of Makasar strait about $600 \mathrm{~km}$ from the capital of Middle Sulawesi Province, Palu city. The other tribes of this Buol regency speak their own vernaculars beside Bahasa Indonesia. Involving other tribes in this regency in the social community, more or less, Buol language will receive new words as loan-words from other tribes' vernaculars such as Bugisese, Mandarese, Makasarese, Torajanese, Kailinese, Javanese, Saluanese, Balantaknese, Pamonanese languages, and other vernaculars that are not mentioned here. In short, there are 30 different vernaculars existing in whole Middle Sulawesi Province, and one of them is Buol language (Friberg, Barbara, 1990).

With respect to the above information, it is generally acknowledged that language is one of the mainly significant and natural forms of person behavior. It always possesses a space in the academic world where its role has changed seriously: at one time the research of language is almost entirely restricted to certain languages, especially those of their speakers are reducing that make those languages experience extinction.

As concentrated on the significance of language, each of the social sciences has expanded; it has encountered language problems within its zone such Psychology, sociology, and anthropology have each investigated language both as a kind of people activity and as a system interconnecting with personality, society, or culture. Consequently, many of linguists have designed techniques for the investigation of language from a number of different aspects. Each of these techniques improves to all the others in preparing theoretical knowledge and the practical problems of the day. For example, one approach has gained a little bit consideration until very recently: Descriptive linguistic which examines languages in terms of their inside structures. It distinguishes from the other approaches in that it concentrates on different aspects of human speech. The traditional wide subject matter and its particular competence to solve certain types of problems convey it into vital relationship with many other disciplines.

With respect to what has been stated above, it can be remarked that language is the manifestation of all these things built up through communication among groups of the community and the culture it represents. Language, in terms of culture is community specific relationships and is complicatedly interconnect with the culture it represents. Language assists members of the community to develop, protect and sustain their characters as individuals and as a group, bringing among them an implication of commonality. Language acts as a device of instruction on the one hand and as a tool of developing relationship with its areas on the other. It assists to develop thoughts that need to be revealed with integrity and solidity. In addition, language has many interrelationships with a diversity of features of human life that it can be probed from different points of view in which linguistics takes part in the essential task for understanding language. 
Gordon (2005) states that linguistics is the science which endeavors to understand language from the point of view of its internal structure in which three major elements of language, as far as language expand out within the series of linguistics, are the structure of expression, the structure of content, and vocabulary. The latter dealing with all the specific relations between expressions and contents are in the common terminology, words and their meanings.

Respecting to the above statements, vocabulary appears and disappears. It is the least constant and even the least characteristic of the three elements of language. That part of the vocabulary which vanishes or fades away most freely is sometimes concerned with as "slang." But even ancient words are always being produced and persistently passing out of active use, to be protected only in literature which is dated by their very presence. While specific types of words are more short-lived than others are, none is absolutely never-ending, and even the most familiar and commonly used words, which might be expected to be most constant. Moreover, in the life history of an individual speaker the birth and death of words is very much more normal than in the language community as a whole. As a result, any language is extinction whenever its speakers increase of being death, let alone if the language is not exerted by its indigenous (native) speakers in their daily life or in their community.

In line with what has been stated above, Gordon (2005) continues stating that there are some different strategies to the categorization of language endangerment. According to him, the total number of languages in the world is 6,912. Of the languages listed, 516 are classified as almost extinct, as "only a few elderly speakers are still a life." A language might be regarded as endangered when it is exerted only by socially isolated old folks, a socially integrated inhabitants away from a child bringing ages, and when it survives only orally, without literacy.

In addition, Rau, et al., (2005) define three groups of endangerment: (1) vanishing languages: no longer learned by children, (2) endangered languages: still learned by children but not expected to be learned by children within ten years, and (3) protected languages: supported by the state and having a large number of speakers. It is approximated that $90 \%$ of the existing oral languages will either be on our deathbed or will have vanished by the end of the century. Thus, there is a very limited window of opportunity to record and renew (regenerate) those languages. Before the researcher of this study investigated this language in 2005, several previous researchers have probed Buol language in general aspects (Garantjang, Ahmad, et al., 1984). Garantjang, et al., did not investigate in the details of this language, but they focused their study in two aspects, like 'morphology and syntax'. They never studied the function words of this language.

Based on the above information, research done by Summer Institute of Linguistics (1985) suggests that among the 735 vernaculars in Indonesia recorded, 637 are endangered with less than 100,000 native speakers. Along with the strong campaign of the government to speak "Good Indonesian" and the fact that English is promoted starting at primary education, the description of multilingualism in Indonesia is unfortunately severely worsen. Specifically, Friberg (1990) states that the total numbers of vernaculars inventoried in Middle Sulawesi are about 30 different local languages. One of these vernaculars written in his vernaculars list is 
Buol language.

Regarding to these facts, it is saddening to say that multilingualism in Indonesia is in a real situation of misfortune or tragedy. While local languages or vernaculars are diverse as the aforementioned local languages which provide a rich array of linguistic research that might be of interest to many scholars worldwide, the preservation of these vernaculars is far from satisfactory. Accordingly, Buol language is very importantly investigated, and in concurrently inventoried to preserve local cultural elements; it also provides contribution toward the local linguistic development in particular and the national linguistic development in general. The statements above pushed the researcher to conduct a study about the function words of Buol language as one of 30 vernaculars existing in Central Celebes (Middle Sulawesi).

\section{Research Methods}

The pattern of this study is a descriptive qualitative. It is based on the process of investigation involving descriptions and interpretations that can be exerted without controlling variables. In other words, this study is qualitative in nature, trying to explain and describe data, which are written in the form of field-notes. This research reveals findings not by tools of statistical procedures or other devices of quantification. Based on this feature, this study is named "qualitative research because its main method of data collection is closely related to observation, interviews, questionnaers, and recording. This research was conducted at one district available in the Capital of Buol regency, called 'Biau district'. The ten informants from this district can be representative of other district population as data sources because these native speakers of Buol language know very well their language, and moreover, they are educated persons graduating from Tadulako University where the researcher of this study as an English lecturer. Further, to obtain the data for this study, four techniques were applied such as the researcher of this study read books related to the topic, recorded the informants' utterances, interviewed the informants in relation to the data given by them, and the informants filled the questionnaire sheets.

\section{Findings and Discussion}

The descriptions of the findings are directed to answer the research question: "What types of function words does Buol language have?" In line with the research problem, the following are the answers of the query above. Based on the findings, it has been found that Buol language has several function words as presented respectively below.

\subsection{Function Words Viewed from Syntactical Features}

When a function word of Buol language is observed on the basis of syntactical features, it cannot form a sentence consisting only one word as a complete utterance. This means that the function word has meaning if it is connected to another word in a phrase or a sentence, for instance, the function words / iyo / 'or,' / a / 'in, at, to,' / agu/ 'and,' will have meanings if they are connected with another word. Let's consider the following examples:

1. / motape iyo mokoyok / 'lazy or diligent'

2. / a gua / 'in the garden,' 


\section{Macrothink

3. / malita agu atin / 'red pepper and salt.'

\subsubsection{The Types of Function Words of Buol Language}

Almost all function words of Buol language cannot experience the process of form changing. The following are the transcript excerpts of function words:

\subsubsection{Noun Determiners}

These sorts of determiners are words that always appear before nouns. This group includes the articles: / te?etu / 'a, the'; other words that indicate that a noun follows:

/ moyabung / 'many', / kamamonu / 'several', / tandanio / 'all', / tong + noun + tong + noun / 'each ... each ... ', / todidik / 'few', / kundi: / 'this', / kundo: / 'those', / kundia / that (near the speaker)', The following are their examples as follows:

1. / te?etu / 'a, the'

2. / moyabung / 'many'

3. / kamamonu / 'several'

4. / tandanio / 'all'

5. / tong $+\mathrm{N}+$ tong $+\mathrm{N} /$ ' each $+\mathrm{N}+$ each $+\mathrm{N}$

6. / tukit / 'every'

7. / todidik / 'few'

8. / kundi: / 'ini'

9. / kundo: / 'that' far from the speaker

/ kundia / 'that' near the speaker
/ te?etu butakio / 'a river'

/ moyabung bole / 'many houses'

/ kamamonu yomi / 'several doors'

/ tandanio tau / 'all persons'

/ tong tau - tong tau / 'each person'

/ tukit ti ina / 'every mother'

/ todidik boyo / 'few fish'

/ kundi: kuyobu / this buffalo'

/ kundo: bole / 'those houses'

/ kundia manuk / 'that hen'

\subsubsection{Modifiers}

Modifiers are words that qualify adjectives and adverbs, limit or intensify their meaning, such as: / ndenge / 'very', / yaut / 'too', / koyo / 'enough', / donggoyo / 'still'. The following are their examples as follows.

1. / ndenge / 'very'

2. / yaut / 'too'

3. / momit / 'enough'

4. / donggoyo / 'still'
/ ndenge koyok / 'very diligent "

/ modidik yaut / 'small too' ( = too small).

/ momit koyo / 'enough nice' ( = nice enough)

/ donggoyo poyopoyong / 'still sleep'

\subsubsection{Subordinate Conjunctions}

A subordinate conjunction introduces a clause that depends of a main or independent clause. 


\section{Macrothink \\ International Journal of English Language Education \\ ISSN 2325-0887 \\ 2013, Vol. 1, No. 3}

The subordinate conjunction is grammatically part of the clause it introduces; it is never separated from its clause by a comma. Further, all the introductory words in the three subordinate clauses, even pronouns or adverbs, may be classified as subordinate conjunction (Frank, 1972). In line with this statement, it has been found that Buol language has several subordinate conjunctions: / inda / 'after', / kelepo / 'although', / agu / 'if', / kai / in order',

/ diayapo / 'before', / ha:y / 'because', / kobu / 'but (=except), / asalio / 'if', / padaha:y /

'whereas', / wakutu / 'when'. To recognize their uses, the following are their examples.

1. / inda / 'after'

2. / kelepo / 'although'

3. / agu / 'if'

4. / kay / 'in order'

5. / diayapo / 'before'

6. / ha:y / 'because'

7. / kobu / 'but' (except)

8. / asalia / ' 'if'

9. / padaha:y / 'whereas'

10. / wakutu / 'when'
/ kito ma?ali mongan inda modigu /

'We may eat after bathing'

/ amo momipi uyot kelepo tio mogiginit /

' Mother washes blanket although she is sick'

/ iko ma:ri moinggay diodot doka kundia agu iko dugupan tau gi:gigi / 'you can lift this big stone if you are helped by other people'

/ tio do:gon mopoyong kay tio mokeleg /

'He must sleep in order that he is healthy'

/ tio di:la ma:li moyako diayapo tio mongan namonamot /

'He may not go before he has breakfast'

/ tia mokokok ha:y tia mongan pale mobuyog/

'I am sick because I eat stale rice'

/ iko tandania ma:li mongambuling kobu ti Ali di:la ma:li /

'All of you may go home but Ali may not'

/ kakai atia mogudup asalio atadan /

'Grandfather shall come if being fetched'

/ iko di:la mokareja padaha:y iko ni:gianno doi /

'You do not work whereas you are given money'

/ tilo du mokareja ato guanueneh wakutu tia noitamo /

'They are working at the rice-field when I come /

\subsubsection{Relative Pronounce}

Relative pronouns refer to noun antecedents which immediately precede them. They 


\section{Macrothink}

introduce adjective clauses in which they serve as subjects or objects (Frank, 1972). Based on this explanation, it has been found that Buol language has three relative pronouns, such as:

/ ku / 'which', / i / 'which, that', / ta / 'who'. Their examples are as follows.

1. / ku / 'which' / buyoli ku nipate nilo ato bi:g gua diapo kinotomon /

'Pig which is killed by them around the garden, has not been found yet'

2. / i / 'which, that' / te? etu bole i nipotali ti uma kundo: mopia yaut /

'The house which is bought by father, too beautiful'

3. / ta / 'who' / te? etu tau ta nomongat a omu kundo: mongambulin mogudup /

'A person who goes to Omu, comes back tomorrow'

\subsubsection{Coordinate Conjunctions}

The coordinate conjunctions join structural units that are equal grammatically. The conjunction comes before the last unit and is grammatically independent of this unit (Frank, 1972). Referring to these function words, it has been found that Buol language has coordinate conjunctions as presented in the following examples below:

1. / agu / 'and' / tin ina momipi agu ti uma mopodigu tawaliku /

'Mother washes and father bathes my young brother'

2. / inda kundo: / after that' / tio nomangon, namonamot inda kundo: tia noyako nokareja/

'He has breakfast after that he goes to work'

3. / dondo: / then'

/ ti uma mongali buang dondo: tio monuang buang kundo: dunganno diodot /

'Father digs a hole and then he fills it with stone'

4. / na:li / 'because of that' / tilo mokarejayon tutu: na:li iko mpmoya doi nilo /

'They have already worked hard na:li you pay his reward'

5. / iyo / 'or'

/ iko ma:li mokareja a bole iyo mokareja a gua /

'You may work at home or work in the garden'

6. / boi / 'but'

/ tilo nonga:non, boi tia diapo /

'They have already eaten but I haven't'

\subsubsection{Transitional Signals / Sentence Linkers}

The two terms written above are synonyms in which the formal devices are used to combine sentences into continuous text. They provide logical relationships that hold between sentences or stretches of text, marked by the use of logical connectors (Mackay et al., 1979). The discourse markers are functions words used to support and enlarge a main idea in a paragraph. With respect to this statement, Buol language has been found having sentence linkers, such as:

1. / condoniyo / 'example'

2. / toto:non / 'actually'

3. / do:ndo / 'furthermore' 
4. / na:li / 'so'

5. / kelepo kodoto / 'even though'

6. / dungan apad gigi / 'in other words'

\subsubsection{Prepositions}

Prepositions as well as conjunctions differ from other parts of speech in that (1) each is composed of a small class of words that have no formal characteristic endings; (2) each indicates syntactic structures that function as one of the other parts of speech. They are classified as structure words rather than as parts of speech (Frank, 1972). In line with this statement, Buol language has been found having several prepositions:
1. $/$ no $=$ halilo / 'about'
13. / duli / 'on'
$2 /$ roe / 'during'
14. / panau / 'under'
3. $/$ na: $=$ kodako $=$ dako $/$ 'to'
15. / bo:ng / 'out'
4. / atuali / 'around'
16. / duayom / inside'
5. / a: = ato / 'in, at'
17. / bi:g / 'beside'
6. / dakun / 'to'
18. / tonguyung / 'at back = behind'
7. / akun / 'to'
19. / butu / 'corner'
8. $/ \mathrm{ni}=\mathrm{li} /$ 'by'
20. / awalio / 'beneath'
9. / unggagi = dagi / 'from'
21. / atuali / 'across' = over'
10. / dungan / 'with'
22. / tungbutak / 'next to'
11. / titinggai dungan / 'together'
23. / kuon = kuni / 'for'
12. / sambe / 'until'
24. / kodoga:ya / 'like (look like)'

\subsubsection{Interrogators}

The interrogators are function words used to ask something that expects a reply supplying an item of information. They refer to interrogative adverbs and pronouns (Quirk and Greenbaum, 1973; Frank, 1972). Based on this statement, Buol language has been found having interrogative adverbs and pronouns. The Buol interrogators do not involve any auxiliary verbs of to be or to do because it does not have them as the English does. The following are the examples of interrogators of Buol language.
1. / komonu / 'when'
2 / amaino / 'where'
3. / na:maino / 'to where'
4. / maino / 'where'
5. / unggagi / 'from where'
6. / kumaino / 'which'
7. / oyo / 'what'
8. / kodo oyo / 'how'
9. / itai / 'who'
10. / kuon tai / 'whose'
11. / nongoyo / 'why'
12. / monu / 'how much/many'

\subsubsection{Modal Auxiliaries}

Modal auxiliaries add to the verb a special semantic component such as ability, obligation, and possibility. In line to this statement, Buol language has been found having modal auxiliaries, such as:
1. / ma: / 'shall, will'
3. / ma:li / 'may' 
2. / dogo:n / 'must'

4. / ma:ri / 'can'

\subsubsection{Aspects}

An aspect referring to certain verbs, often with accompanying adverbial expressions, may indicate whether an event is to be regarded as a single point on a time continuum, a repetition of points, or a single duration with a beginning, a middle and an end. It is the aspect of duration that a verb most readily expresses through the progressive forms of the tenses (Frank, 1972). Based on this explanation, Buol language has been found having function words that are concerned with aspect. The following are the examples of aspect stated below:
1. / du / 'going on'
/ no:laud / 'already'

\subsubsection{Interjections}

Interjections are function words used to express human's feelings, such as sad, hurtful, astonishing, disgusted, angry, and admiring. In general, the interjection refers to an attitude of (1) negative, (2) positive), (3) astonish, and (4) expecting an attention that depends on the sentence purpose that follows it. Referring to this explanation, Buol language has been found possessing function words of interjections:
1. / nai !/'ah!
2 / dugupe ! ' 'help !'
3. / o?o:! / 'yes!'
4. / di:la! / 'no!'
5. / de? ! / 'not!'
6. / wa! / 'ah!'

$$
\begin{aligned}
& \text { 7. / uyatepo ! / 'wait !' } \\
& \text { 8. / che ! / 'cis!' } \\
& \text { 9. / kopisiko ! / 'that taught you a good lesson!' } \\
& \text { 10. / dondo: kinamitannio ! / 'serves you right! } \\
& \text { 11. I ya ambune ! / 'my God!' } \\
& \text { 12. / ka:ti ! / ' poor thing!, what a pity!' }
\end{aligned}
$$

The further descriptions of the findings are directed to answer the research question: "How do function words of Buol language appear in a sentence, a clause, and a phrase?" In line with the research problem, the following are the answers of the question above.

Based on the findings, it has been found that Buol language has several function words that have certain patterns in a phrase, a clause, and a sentence presented respectively below.

\subsection{Function Words Inspected from Syntactic Characteristics}

Syntactically, the features of function word of Buol language could be identified from their patterns in a phrase, a clause or a sentence. The following are the transcript excerpts of function words in a phrase, a clause or a sentence.

\subsubsection{Positions of Function Words in a Phrase}

Before presenting the excerpts of Buol function words, the researcher needs to reveal what the phrase is. Phrase is a small unit of syntax together its function as a connector. So phrase can consist of one or more words (Samsuri, 1981). Based on this definition, the Buol function words are viewed from two type patterns such as (1) endocentric phrase, and (2) exocentric phrase. Let's consider the following examples.

3.2.2 Function Words in an Endocentric Phrase 


\section{Macrothink}

A pattern is called endocentric when its distribution patterns are similar to the second, the third, or one of its immediate constituents (Samsuri 1981). The attributively endocentric

pattern is indicated by one of immediate constituents acting as a head $(\mathrm{H})$ and another one as a modifier (M). Referring to these statements, it has been found that Buol language has several function words having (a) the attributively endocentric patterns, and (b) the coordinately endocentric patterns.

(a) The Attributively Endocentric Patterns. Here the examples are below.

(1) Indefinite Numeral (Determiners) $\frac{\text { Nodifien }}{\text { Determiner }}+\frac{\text { Head }}{\text { Noun }}$

$$
\begin{aligned}
& / \frac{\mathrm{M}}{\text { moyabung }}+\frac{\mathrm{H}}{\text { tayadun }} / \text { 'many }+ \text { mangoes' } \\
& / \frac{\mathrm{M}}{\text { kamamonu }}+\frac{\mathrm{H}}{\text { buyuli }} / \text { 'several + pigs' } \\
& / \frac{\mathrm{M}}{\text { te? etu }}+\frac{\mathrm{M}}{\text { pape }} / \mathrm{a}+\text { banana' } \\
& / \frac{\mathrm{M}}{\text { todl:d:k}}+\frac{M}{\text { utan }} / \text { 'some + vegetable' }
\end{aligned}
$$

(2) Noun + Demonstrative Pronounce (Determiners) $\frac{\text { Head }}{\text { Noun }}+\frac{\text { Modifien }}{\text { Determinen }}$

$$
\begin{aligned}
& / \frac{\mathrm{H}}{\text { bole }}+\frac{\mathrm{M}}{\mathrm{kundia}} / / \text { 'house }+ \text { that' (= that house) } \\
& / \frac{\mathrm{H}}{\mathrm{kuy}}+\frac{\mathrm{M}}{\mathrm{kum} d \mathrm{t}} / \text { 'buffalo + this' (= this buffalo) }
\end{aligned}
$$

(3) Noun + Manner (Qualifier) $\frac{भ}{\text { Noun }}+\frac{\mathrm{M}}{\text { Qualifien }}$

$$
/ \frac{\mathrm{H}}{\text { yalu }}+\frac{\mathrm{M}}{\text { kumbu }} / \text { 'rice }+ \text { this afternoon' (the afternoon rice) }
$$


$/ \frac{\mathrm{H}}{\mathrm{utan}}+\frac{\mathrm{M}}{\mathrm{rew}} /$

'vegetable + now' (now vegetable)

$/ \frac{\mathrm{H}}{\text { boyo }}+\frac{\mathrm{M}}{\text { koyaung }} /$

'fish + yesterday' (yesterday fish)

$/ \frac{\mathrm{M}}{\text { bukung }}+\frac{\mathrm{M}}{\text { gudug }} /$ 'stock + tomorrow' (tomorrow stock)

(4) Adverbs of Times (Qualifiers) as the function words + Adjective $\frac{M}{A d v e r b}+\frac{H}{Q u a l i f i e s}$

$$
\begin{aligned}
& / \frac{\mathrm{M}}{\text { diavuba }}+\frac{\mathrm{H}}{\text { mokokok }} / \text { 'always }+ \text { sick } \\
& / \frac{\mathrm{M}}{\text { dongeyo }}+\frac{\mathrm{H}}{\text { moinget }} / \text { 'still + angry' } \\
& / \frac{\mathrm{M}}{\text { moyage }}+\frac{H}{\text { kubumgoy }} / \text { 'rarely }+ \text { noise' }
\end{aligned}
$$

(5) Verb + Adverbs of Manners (Qualifiers) $\frac{H}{V_{\text {avb }}}+\frac{\mathrm{M}}{\text { Quali: }}$

$$
\begin{aligned}
& / \frac{\mathrm{r}}{\text { unkoywu }}+\frac{\mathrm{M}}{\text { undue }} / \text { 'cook }+ \text { tomorrow' }
\end{aligned}
$$

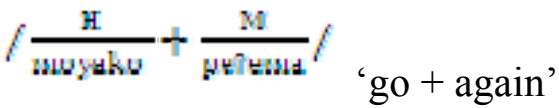

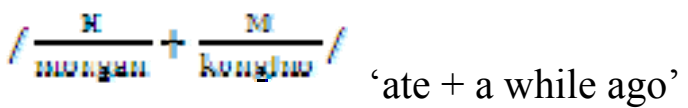

(6) Adverbs of Manners (Qualifiers) + Verb $\frac{N}{\text { Qualitien }}+\frac{H}{V e r b}$

$$
/ \frac{\mathrm{N}}{\text { moyagen }}+\frac{\mathrm{M}}{\text { modigu }} / \text { 'rarely }+ \text { bath' }
$$


$/ \frac{\mathrm{M}}{\mathrm{du}}+\frac{\mathrm{H}}{\text { momipl }} /$ 'being + washing'

$/ \frac{M}{\text { kama }}+\frac{M}{\text { mogopit }} /$ 'perhaps + stop by'

(7) Adverbs of Manners (Qualifiers) + Verb + Adverbs of time $\frac{M}{A d v e r b}+\frac{M}{\text { Verb }}+\frac{M}{A d v e v b}$

$/ \frac{\mathrm{m}}{\text { mogudup }}+\frac{\mathrm{H}}{\text { nottame }}+\frac{\mathrm{m}}{\mathrm{ag}} /$ 'tomorrow + come + again'

$/ \frac{\mathrm{M}}{\text { moyagen }}+\frac{\mathrm{H}}{\text { mokaraja }}+\frac{\mathrm{M}}{\text { gut }} /$ 'rarely + work + in the evining'

$\left./ \frac{\mathrm{N}}{\text { diamba }}+\frac{\mathrm{H}}{\text { mongan }}+\frac{\mathrm{M}}{\text { koyama }}\right\rangle$ 'always + eat + yesterday'

\section{(b) Coordinately Endocentric Patterns}

The features of this pattern are indicated by involving conjunctions via joining two or more main constituents having the same status and acting as heads (content words). The conjunctions acting as function words in Noun Phrase, Verb Phrase, and Adjective Phrase are: / dungan / 'with', / iyo / 'or', / agu / 'and', / boli / 'again', / boi / 'but'. The following are their examples.

(1) The function word / dungan / 'with' in the Noun Phrase is pinched by Nouns.

$$
\begin{aligned}
& \text { Noun }+ \text { Preposition }+ \text { Noun } \\
& / \frac{\text { Noun }}{\text { yomi }}+\frac{\text { Preposition }}{\text { dungan }}+\frac{\text { Noun }}{\text { bomi }} / \text { 'door }+ \text { with }+ \text { window' } \\
& / \frac{\text { Noun }}{\text { tendeng }}+\frac{\text { Pregosition }}{\text { dungan }}+\frac{\text { Noun }}{\text { bonggukut }} / \text { 'cat }+ \text { with }+ \text { mouse' } \\
& / \frac{\text { Noun }}{\text { malita. }}+\frac{\text { Pregosition }}{\text { dungen }}+\frac{\text { Ncun }}{\text { atim }} / \text { 'pepper }+ \text { with }+ \text { salt' }
\end{aligned}
$$

(2) The function word / iyo / 'or' in the Noun Phrase is pinched by Nouns

$$
\text { Noun }+ \text { Conjunction }+ \text { Noun }
$$




$$
\begin{aligned}
& / \frac{\text { Noun }}{\text { poduk }}+\frac{\text { Conjunction }}{\text { iyo }}+\frac{\text { Noun }}{\text { babandi }} / \text { 'knife }+ \text { or }+ \text { mattock' } \\
& / \frac{\text { Noun }}{\text { utan }}+\frac{\text { MConjunction }}{\text { iyo }}+\frac{\text { Noun }}{\text { dabu }} / \text { 'vegetable }+ \text { or }+ \text { chilli' } \\
& / \frac{\text { Noun }}{\text { dugu }}+\frac{\text { Conjunction }}{\text { iyo }}+\frac{\text { Noun }}{\text { boyo }} / \text { 'meat }+ \text { or }+ \text { fish' }
\end{aligned}
$$

(3) The function word / iyo / 'or' in the Verb Phrase is pinched by Verbs

$$
\text { Verb + Conjunction + Verb }
$$

$$
\begin{aligned}
& / \frac{\text { Verb }}{\text { moyaho }}+\frac{\text { Conjunction }}{\text { iyo }}+\frac{\text { Verb }}{\text { toyan }} / \text { 'go }+ \text { or }+ \text { remain' } \\
& / \frac{\text { Fevi }}{\text { motumargit }}+\frac{\text { cenpunstion }}{\text { iyg }}+\frac{\text { Fevb }}{\text { mohilii }} / \text { 'cry + or + laugh' } \\
& / \frac{\text { Ferb }}{\text { mongini }}+\frac{\text { Conjumetion }}{\text { jyo: }}+\frac{\text { Verb }}{\text { mogunggah }} / \text { 'urinate }+ \text { or }+ \text { shit' }
\end{aligned}
$$

(4) The function word / iyo / in the Adjective Phrase is pinched by Adjective Phrases

$$
\text { Adjective + Conjunction + Adjective }
$$

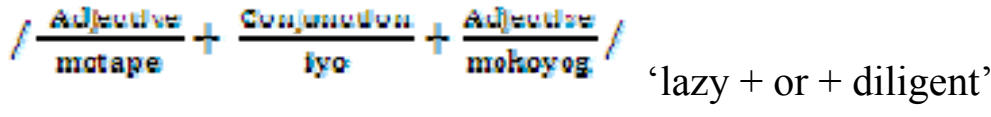

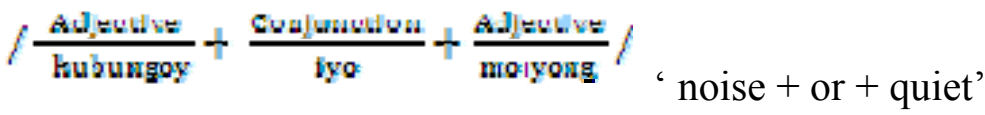

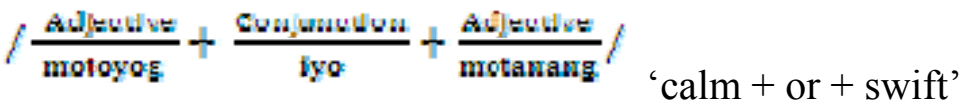

(5) The function word / agu / 'and' in the Verb Phrase is flanked by verbs

$$
\begin{gathered}
\text { Verb }+ \text { Conjunction + Verb } \\
/ \frac{\text { Ycob }}{\text { modigu }}+\frac{\text { Eonjumstion }}{\text { agu }}+\frac{\text { Yarb }}{\text { momipi }} / \text { 'bath }+ \text { and }+ \text { wash' } \\
/ \frac{\text { Verb }}{\text { mohoyutu }}+\frac{\text { conjumetion }}{\text { agu }}+\frac{\text { Verb }}{\text { mogropeng }} / \text { 'cook }+ \text { and }+ \text { fry' }
\end{gathered}
$$


$/ \frac{\text { Verb }}{\text { moturu }}+\frac{\text { Conjurction }}{\text { agu }}+\frac{\text { Verb }}{\text { modenena }} /$ 'burn + and + toast'

(6) The function word / agu / 'and' in the Adjective phrase is clamed by Adjectives

$$
\text { Adjective + Conjunction + Adjective }
$$

$$
\begin{aligned}
& / \frac{\text { Adjective }}{\text { mopani }}+\frac{\text { Conjunction }}{\text { agu }}+\frac{\text { Adjective }}{\text { mohoyog }} / \text { 'smart }+ \text { and }+ \text { industrious' } \\
& / \frac{\text { Adjective }}{\text { motape }}+\frac{\text { conjunction }}{\text { agu }}+\frac{\text { Adjective }}{\text { tuyong }} / \text { 'lazy }+ \text { and }+ \text { stupid' } \\
& / \frac{\text { Adjective }}{\text { mopanggat }}+\frac{\text { Conjunction }}{\text { agu }}+\frac{\text { Adjective }}{\text { mogite }} / \text { 'tall }+ \text { and }+ \text { thin' }
\end{aligned}
$$

(7) The function word / agu / 'and' in the Noun Phrase is hemmed by Nouns

$$
\begin{aligned}
& \text { Noun }+ \text { Conjunction }+ \text { Noun }
\end{aligned}
$$

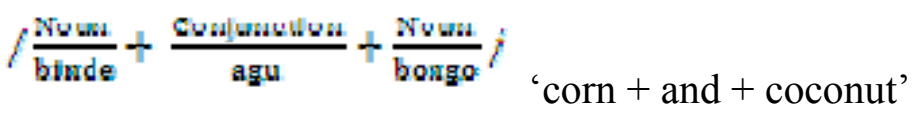

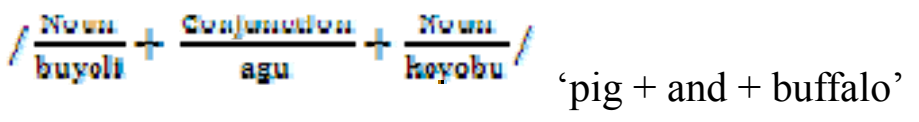$$
/ \frac{\text { Noun }}{\text { buje }}+\frac{\text { Conjunation }}{\text { ayu }}+\frac{\text { Noun }}{\text { diuht }} / \text { 'fish }+ \text { and }+ \text { dog' }
$$

(8) The function word / boli / 'also' in the Adjective Phrase is wedged by Adjectives

$$
\text { Adjective }+ \text { Adverb }+ \text { Adjective }
$$

$$
\begin{aligned}
& / \frac{\text { Adjeatlve }}{\text { modoha }}+\frac{\text { Adverb }}{\text { boli }}+\frac{\text { Adjeative }}{\text { mopanggat }} / \text { 'big + also + tall' } \\
& / \frac{\text { Adjective }}{\text { mopani }}+\frac{\text { Adverb }}{\text { boli }}+\frac{\text { Adjective }}{\text { mohoyog }} / \text { 'smart }+ \text { also + diligent' } \\
& / \frac{\text { Adjective }}{\text { tuyong }}+\frac{\text { Adverb }}{\text { boli }}+\frac{\text { Adjective }}{\text { motape }} / \text { 'stupid + also + lazy' }
\end{aligned}
$$

(9) The function word / boi / 'but' in the Adjective Phrase is flanked by Adjectives 


\section{Macrothink

Adjective + Conjunction + Adjective

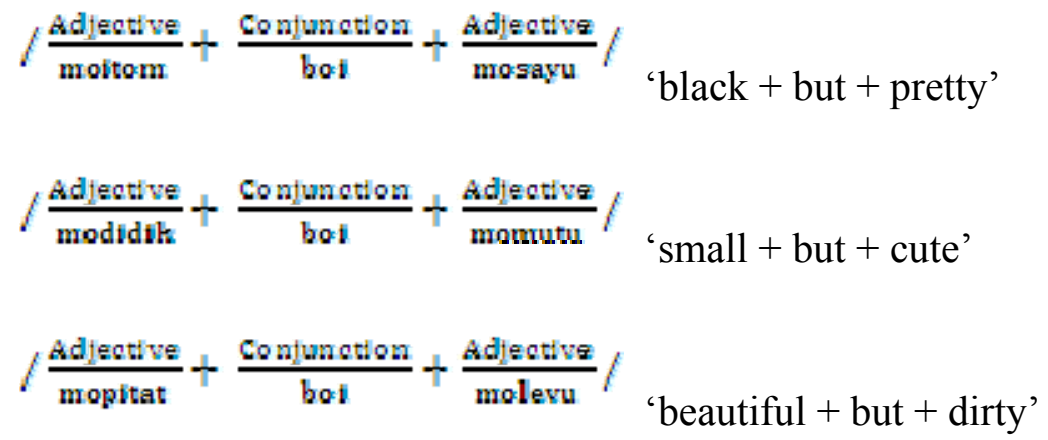

3.2.3 The Positions of Function Words in an Exocentric Phrase Type

A pattern is named exocentric when its combinations have different form classes from its immediate constituents. Since these class combinations are not similar to one of its constituents, the exocentric pattern always does not have a head. The directly particle exocentric patterns have been found in Buol language by using prepositions. The prepositions act as function words combining with nouns. Here the examples are presented below.

(1) The function words / a / 'at, in' goes before the noun. The following are the examples of prepositions as the function words of Buol language.

\section{1. a Preposition + Noun}

1. / a / 'at, in'

/ a gua / 'in the garden'

2. / ato / 'between'

/ ato oyototo nuko / 'between fences'

3. / dungan / 'with'

/ dungan tawali / 'with young bother'

4. / unggagi / 'from'

/ unggagi butakio / 'from the river'

5. / dagi / 'from'

/ dagi duayom bole / 'from inside house'

6. / kuni / 'for'

7. / kodogaya:n / 'look like'

/ kuni monugong / 'for brother/sister in law'

8. / abo:ng / out side

9. / loyot / 'between'

/ kodogaya:n digo / 'looks like monkey'

/ abo:ng bole / 'out side house'

/ loyot tonuk / 'between fences (see no. 2 above)

10. / kodako / 'to'

11 / na: / 'to'

/ kodako gua / 'to the garden'

/ na: Amerika / 'to America'

\subsubsection{The positions of Function Words in a Clause}

The function words of Buol language are described in two types of clause: Independent

\section{Clause and Dependent Clause}

(1) Independent Clause - Independent clause can stand alone as a complete sentence, and

can appear either as the basic sentence or a derivative sentence. It can appear in a compound sentence by involving conjunctions as the function words: / agu / 'and', / boi / 'but', / iyo / 'or', / don:do / 'and then'. Here their examples are presented respectively below. 
1. The function word / agu / 'and'

/ tia monogot dungit agu iko monogot tian /

/ tilo moduti biabad agu kito moyanong buyoli /

/ tio mopokobirisi te? etu bole agu iko monobong moyabung boyo /

2. The function word / boi / 'but'

/ kito momea a bonggil boi kito di:la monangi a dogot /

/ ti inanoto motumangit boi ti umanoto kovu mokiki /

/ tilo mokareja mobugot boi iko kovu mopoyongon /

3. The function word / iyo / 'or'

/ iko ma:li monokopo bimi iyo iko moyanong buyoli /

/ tilo ma:li monguatik iyo mokiki / 2013, Vol. 1, No. 3

4. The function word / do:ndo: / 'afterwards', 'so'

/ ti uma mojay:o do:ndo: tio monalembak /

/ ti ina monogot tian do:ndo: tio ma:te /

/ tio motape yaut modigu do:ndo: tio molebu tia-tia /

'I am tooth ached and you are stomached'

'They seek fruits and we hunt a pig'

'She cleans a house and you nets many fishes'

'We live in the beach but we do not swim on the sea'

'Our mother cries but our father just laughs'

'They work hard but you just sleep'

'You may catch goat or you hunt pig'

'They may exclaim or laugh'

'Father berserks afterwards he kicks'

'Mother is stomached afterwards she died'

'She is very lazy to bath so, she is dirty now'

5. The function word / kelepo kodoto / 'however'

/ ti umaku nogotad kunimu kelepo kodoto iko di:la noitamo /

/ ti nadidinoto nokoyutu boyo kelepo kodoto tio diapo mongan

'My father has invited you, however, you do not come'

'Our aunt has cooked fish, however she has not eaten yet'

2. Dependent Clause - The dependent clause cannot stand alone as a complete sentence but it can become a minor sentence. The dependent of the clause can be recognized when the clause occurs in a compound sentence involving subordinate conjunctions as the function words, for examples: / ha:y / 'because', / kelepo / 'although', / agu / 'if' and', / asaylio / 'if', / kobu / 'but (except)', / padaha:y / 'even though' To know how to use them in the dependent clauses, the following data can show us as in:

1. The function word / ha:y / 'because'

/ tio di:la mongan ha:y tio mokokok /

/ ti Amir mogotat kunilo ha:y tilo ma: mongan /

/ ti uma di:la motami monokop te?etu odiuk ha:y tinggidio notoyong /

'She does not eat because she is sick'

'Amir call them because they shall eat' Father cannot catch a dog because his led broken' 
2. The function word / kelepo / 'although'

/ ti ina mokoyutu kelepo tia monogot tian / 2013, Vol. 1, No. 3

/ ti uma mokareja a gua kelepo tio di:la potoyo gua /

/ tilo ma: monangiadogot kelepo tilo nigian ni uma /

3. The function word / agu / 'if'

/ ti boiya mogu mongotoyo paye agu ti uma mogu mongigi doi kunio /

/ tilo di:la mogu mokareja agu tilo moma:d bole /

/ ti nadidiku mogu motomore agu tio nopokopioyon bolenio /

4. The function word / asaylio / 'as long as'

/ ti boiya mogu momutak tomuyan asaylio tio dugupan /

/ tilo ma: mopokopioyon be? etu bole asaylio tilo atadan /

/ ti umaku ma: mogutu tukad asaylio iko modoyo kunio doi /

5. The function word / kobu / 'but' (except)

/ tandanio tau ma:li moyako kobu iko di:la /

/ tandanio kita do:gon motakod vukid boiyamu di:la do:gon /

/ tandanio tilo ma: mokait yondad kobu ti Amir monoug bunga /

6. The function word / padahay / 'even though'

/ iko di:la moginggay diodot kundo padahay iko mokeleg /

/ kito motape mokareja padahay kito ni:igianno doi /

/ ti Amir nokoyak padahay tio di:la atadan /

\subsubsection{The positions of Function Words in a Sentence}

The function words of Buol language have been found appearing in three types of sentence: (1) compound sentence, (2) complex sentence, and (3) compound-complex sentence. Here their examples are presented below.

\subsubsection{Function Words in Compound Sentences}

The complex sentence of Buol language has been found having two or more full predications in the form of independent clauses. The function words in the compound sentence have coordinately endocentric patterns, such as: Clause + Conjunction + Clause. The function 
words as conjunctions usually used in Buol language are / agu / 'and', / do:ndo: / 'then', / yaud dako / 'after that', / ha:y kundo: / 'that is why'. Here their examples are revealed below.

1. The function word / agu / 'and'

/ tilo monogot tian agu kito monogot dungit /

/ tio motumangit agu iko monuatik /

/ iko momuko bomo agu ti ina monundi yomi

2. The function word / do:ndo: / 'then'

/ ti uma mongan pale do:ndo: monginum unggak /

/ ti tina nopopolitu taditi kundo: do:ndo: ti taditi kundo: mongan pale /

/ tilo kumavut kodako bonggil do:ndo: tilo monangi a dogot /

3. The function word / yaud dako / 'after that'

/ tia noginggayo unggak yaud dako tia nodigu /

/ tio noyopod pepe a gua yaud dako tio nodoyo pepe kundo: dako bole /

/ tilo noyako todidi - todidik yaud dako tilo nokumavut /

4. The function word / ha:y kundo: / 'so'

/ iko nokareja mobugot ha:y kundo: iko ma:li nongambuling /

/ tio nodigu yaud dako tio do:gon modugup kunimu /

/ ti uma notali kunimu bodu yaud dako iko do:gon mokoyog mokareja /

'They are stomached and we are tooth ached'

'He cries and you exclaim'

'You open the door and mother shuts the window'

'Father eats rice then drinking water'

'Mother seats that kid then the kid eats rice'

'They run to the beach then swimming on the sea'

'She carries away water after that she baths'

'He cut banana tree in the garden after that he brings that bananas to the house'

'They walk slowly after that they run'

'You have worked hard so you may go'

'He has bathed so she must help you'

'Father has bought cloth for you so you must work diligently'

\subsubsection{Complex Sentences}

The complex sentence is a sentence possessing two or more full predications. One of these is an independent clause (or, main clause) that is the same as the form of the simple sentence, and one or more of these are dependent clauses (or subordinate clauses). The complex sentence of Buol language has the objectively exocentric types. The complex sentence is called the objectively exocentric construction when the object of complex sentence does not have the same function in a complex sentence as any one of its immediate constituents. The function words as conjunctions used in the complex sentence are found as

follows: / inda / 'after', / diyapo / 'before', / ha:y / 'because', / kelepo / 'although', / agu / 'if', / asaylio / 'as long as', / wakutu / 'when', / ku, i, ta / 'which, that, who'. Let's consider 
their examples below.

1. The function word / inda / 'after'

/ tio mongali guamoamek inda tio norojiki namonamot /

/ buaiku modigu inda tio nomipi bodunio

2. The function word / diyapo / before'

/ tilo ma:li mongan diyapo ti umanoto moitamo /

/ ti boiya do:gon moyako diyapo gui moitamo /

3. The function word / ha:y / 'because'

/ ti kakai ma: mogiyayag ha:y iyagu momuka:gi /

/ tio mokokok ha:y tio nongan talon /

4. The function word / kelopo / 'although'

/ tia mokareja kelepo tia mokokok /

/ tio mongan kelepo limonio molevu /

5. The function word / agu / 'if'

/ tilo ma:li mokareja agu noilaud tilo mongan /

/ ti tauwalimu do:gon modigu agu noilaud tio nokoyutu dugu /

6. The function word / asaylio / 'as long as'

/ ti ombunio ma:li mongan asaylio noilaud tio nodigu /

/ tia ma: poyong asaylio noilaud tia mokareja /

7. The function word / wakutu / 'when' / tia donggoyo morojiki wakutu tilo mogotad kunaku /

/ tilo du mopoyong wakutu tia noitamo /

8.a The function word / ku, / 'which, that, who'

/ ti inatoto notunu boyo ku nikailan ti umanoto /

/ tilo mokotamu buyoli ku nipateinoto koyaung /

8.b The function word / i / 'which, that, who' / bimi i taliniu kundo: modoko yaut / / vuayo i niyundokinoto koyaung, noilaud

'He plows rice-field after he has breakfast'

'My wife takes a bath after she washes her dress'

'They may eat before our father comes'

'Grandma must go before the evening comes'

'Grandpa will sail because the moon appears'

'She is sick because she eats chalk'

I work although I am sick'

He eats although his hands are dirty'

'They may work if they have eaten'

'Your young brother must take a bath if he has cooked meat'

'His grandson may eat as long as already he eats (he has already eaten)'

'I shall sleep as long as already I work (I have already worked).

'I still eat when they call me'

'They are sleeping when I come'

'Our mother burns fish which is caught by our father'

'They found the pig which was killed by us yesterday'

'The goat that you buy is big very (is veryl big'

'The crocodile which was stabbed by them 
novutod /

8.c The function word / ta / "which, that, who'

/ te?etu tau ta nogopit ato boleku noyakoyon /

/ te?etu manuk ta nongan bugotniu nipate yesterday, has been rotten'

'A person who call on at my house has gone yesterday'

'The hen that ate your rice, has been cut'

\subsubsection{Compound Complex Sentences}

Compound complex sentences contain two or more independent clauses and one or more dependent clauses. Such sentences in Buol language use function words as conjunctions. Here their examples are found in Buol language using / ku /, / i / 'which, that, who', / agu / 'and'. The following are their examples presented below.

1. The function word / $\mathrm{ku} /$ in the compound complex sentences

/ tiaa nonitu agu nobaca tulit ku nitaguan ni uma koyaung /

'I have investigated and read a letter that is kept by father'

/ tio notunu agu nokoyutu boyo ku nikailan ti uma /

'She burns and cooks fish which is caught by father'

/ tilo monangi agu modigu a dogot ku molevu yaut /

' They swim and take a bath in the sea that is very dirty'

2. The function word in compound complex sentences: /... i ...ku.../ ' $\ldots$ which, that, who /

/ ti nadidi nomubok tending i nongan boyo ku nitalinilo ato kupabayanjaan /

'Aunt beats a cat which eats fish that is bought by them in the market'

/ tia mogotad kunilo i dumongan pepe ku niwundog ti inanoto /

'I call them who are eating bananas that was cooked by our mother'

/ ti uma nobubog kuni pobayu i nodogo manuk ku nitali ti inaku ato bonggil /

'Father beats a merchant who brings a hen that is bought by my mother at the beach'

\section{Conclusion and Suggestion}

\subsection{Conclusion}

Based on the findings of descriptive data of the function words, Buol language has been discovered dealing with ten categories of function words. Those function words are as follows:

(1)Noun determiner - is a word usually appearing before a noun. It describes the amount of a noun, (2) Qualifier - is an adjective word modifying an adjective, an adverb, a verb, and a noun, (3) Preposition - is a word used to form a prepositional phrase. It usually appears before a noun, and an adjective functioning as an adverb, (4) Coordinate Conjunction - combines structural units that are identical grammatically. The conjunction appears before the last unit and is grammatically independent of this unit, (5) Interrogator - is a word used to ask information, (6) Subordinating conjunction - introduces a clause that depends on a main, or independent clause. The subordinate conjunction is grammatically part of the clause it introduces; it is never separated from its clause by a comma (Frank, 1972), (7) Transitional Signals / Sentence 
Linkers - are exerted to combine sentences into continuous text. They provide logical relationships that hold between sentences or stretches of text, marked by the use of logical connectors (Mackay et al., 1979), (8) Modal Auxiliaries - are words used to ask something that uncertainly happens. The modal auxiliaries of Buol languagealways appear before a predicator, (9) Interjection - is a word used to present humans' feelings, (10) Aspect words - deal with certain verbs, often with accompanying adverbial expressions, may indicate whether an event is to be considered as a single point on a time continuum, a repetition of points, or a single duration with a beginning, a middle and an end. It is the aspect of duration that a verb most readily present through the progressive forms of the tenses (Frank, 1972).

\subsection{Suggestions}

Buol language is one of 30 vernaculars in Central Sulawesi that will be affected by loan words from speakers of other vernaculars around it. Its indigenous speakers are about 300.000 people living at five districts in Buol regency. Its new generation speakers almost forget many vocabularies, and are reluctant to use this language in their daily live. Only old men still know well the original vocabularies and grammars of this language. Its vocabularies in terms of function words in particular, and its content words in general might be extinction if they are not investigated. Therefore, only the loan words will be dominant in this language because its original vocabularies have lost from the new generation speakers' brains.

To keep the preservation of this vernacular from extinction, it is suggested that this language must be inventoried, and noted. It is also suggested that any researchers who are interested in a scientific research, should conduct another investigation to probe other aspects of Buol language in general, and function words in particular.

\section{References}

Aryl, D. Jacobs, L. C., \& Razavieh, A. (1979). Introduction to Research in Education. New York: Holt, Rinehart and Winsto.

Berg. B. L. (1989). Qualitative Research Methods for the School. London: Allyn and Bacon, Inc.

Bogdan, R. C. (1998). Qualitative Research Introduction: An Introduction to Theory and Methods. Boston: Allyn and Bacon, Inc.

Frank, M. (1972). Modern English: a practical reference guide. New Jersey: Englewood Cliffs.

Friberg, Barbara. (ed.). (1990). Balantak. In Sulawesi language texts. Language Data, AsianPacific Series, 15. Ujung Pandang: Summer Institute of Linguistics, 7-22.

Garantjang, Ahmad, Amir Kadir, Dahlan Kajia, \& Zobra Mahmud. (1982). Strucktur Bahasa Buol. Pusat Pembinaan Bahasa Departmen Pendidikan dan Kebudayaan RI, Jakarta.

Garantjang, Ahmad, Dahlan Kajia, \& Hasan Basri. (1984). Morpology dan Sintaksis Bahasa Buol. Pusat Pembinaan Bahasa Departmen Pendidikan dan Kebudayaan RI, Jakarta. 
Gordon, Raymond G. Jr. (2005). Ethnologue: Languages of the world. Fifteen Edition. SIL International.

Keraf, G. (1969). Tata Bahasa Indonesia. Jakarta: Penerbit Nusa Indah.

Kridalaksana, H. (1982). Kamus Linguistik. Jakarta: PT. Gramedia.

Miles, B. M., \& Huberman, A. M. (1989). Qualitative Data Analysis. London: Beverly Hills, Saga Publications, Inc.

Patton, M. G. (1980). Qualitative Evaluation Methods. California: Beverly Hills, Saga Publications, Inc.

Parera, J. D. (1976). Pengantar Linguistik Umum. Plores: Penerbit Nusa Indah.

Quirk, R., \& Greenbaum, S. (1973). A University Grammar of English. New York: Longman.

Rau, D. Victoria, Meng-Chien Yang, \& Maa-Neu Dong. (2005). Endangered language documentation and transmission. Journal of National Council of Less Commonly Taught Languages (NCOLCTL), University of Wisconsin at Madison, 53-76. Retrieved in October, 2005.

Robins, R. H. (1980). General Linguistics, An Introductory Survey. New York: Longmans Ltd.

Samsuri. (1981). Analisa Bahasa. Jakarta: Penerbit Erlangga.

Stryker, S. (1969). Applied Lingustics, Principles and Techniques. English Teaching Forum, Vol. II, No. 5.

Taylor, S. J. \& Bogdan, R. (1984). Introduction to Qualitative Research: The Research for Meaning. New York: John Wiley.

Verhaar, J. W. W. (1982). Pengantar Linguistik, Jilid I. Jogyakarta: Gaja Mada University Press.

\section{Copyright Disclaimer}

Copyright reserved by the author(s).

This article is an open-access article distributed under the terms and conditions of the Creative Commons Attribution license (http://creativecommons.org/licenses/by/3.0/). 